\title{
Pengabdian Kepada Masyarakat Pelatihan Daur Ulang Sampah pada Siswa Sekolah Dasar di SDN 03 Cempaka Putih, Ciputat, Tangerang Selatan
}

\author{
Riris lindiawati Puspitasari ${ }^{1}$, Irawan Sugoro $^{2}$, Dewi Elfidasari ${ }^{3}$, Analekta Tiara Perdana $^{4}$ \\ ${ }^{1,3,4}$ Program Studi Biologi, Fakultas Sains dan Teknologi, Universitas Al Azhar Indonesia, Jakarta \\ ${ }^{2}$ Badan Tenaga Nuklir Nasional (BATAN), Tangerang Selatan
}

Penulis untuk Korespondensi/Email: riris.lindiawati@uai.ac.id

\begin{abstract}
Abstrak - Telah dilakukan kegiatan sosialisasi dan pelatihan daur ulang sampah bagi siswa sekolah dasar. Kegiatan ini bertujuan untuk meningkatkan wawasan tentang sampah dan daur ulang sampah kepada anak-anak. Manfaat kegiatan ini yaitu dapat berkontribusi pada pengurangan sampah tidak yang tidak membusuk dan memberikan pengetahuan dalam penanganan sampah sejak dini sehingga terwujud generasi yang peduli terhadap sampah. Kegiatan berlokasi di SD Negeri 03 Cempaka Putih Ciputat Timur, Tangerang Selatan. Siswa yang terlibat yaitu kelas 4 dan 5, berjumlah sekitar 60 orang. Metode yang dilakukan yaitu sosialisasi program, peningkatan pemahaman siswa, dan monitoring. Sosialisasi program dilakukan dengan memberikan materi di kelas secara interaktif. Pemahaman siswa dapat diketahui dengan mengadakan lomba daur ulang sampah yaitu melihat produk kreativitas siswa untuk mengubah sampah menjadi benda yang berguna. Kegiatan monitoring dilaksanakan setelah seluruh rangkaian kegiatan selesai, dengan mengamati perubahan perilaku siswa untuk memanfaatkan sampah di sekitarnya. Berdasarkan pengamatan di lokasi didapatkan bahwa pemahaman siswa untuk mendaur ulang sampah dan mengembangkan ide kreatif mengubah sampah menjadi benda yang bermanfaat meningkat.
\end{abstract}

Kata Kunci - Siswa Sekolah Dasar, Daur Ulang, Sampah

Abstract - Socialization and recycling training for elementary school students has been carried out. The aim of activities were to improve insights on garbage and recycling waste to children. The benefit of this activity was that it can contribute to the reduction of non-decaying waste and provide knowledge in the handling of garbage from an early age so that we could have generation who cares about the waste. The activity was located at SD Negeri 03 Cempaka Putih Ciputat Timur, South Tangerang. The students involved were 4th and 5th grade, about 60 children. The methods used were the socialization of the program, improving students understanding, and monitoring. Socialization of the program was done by giving the material in the class interactively. Understanding students could be known by holding waste recycling contest that looked at student's creativity products to convert waste into useful objects. Monitoring activities were carried out after the entire series of activities had been completed, by observing changes in student behavior to utilize the surrounding waste. Based on on-site observation it was found that student's understanding to recycle garbage and develop creative ideas transformed waste into useful items increased. 


\section{PENDAHULUAN}

$\mathrm{P}$ ola pikir untuk peduli terhadap sampah harus diperkenalkan sejak dini. Anak-anak memiliki daya ingat yang kuat dan mudah menyerap informasi. Pemberian wawasan daur ulang sampah sejak kecil, dapat membuat anak lebih bijak melihat sampah. Anak-anak dapat lebih kreatif untuk menghasilkan produk daur ulang sampah karena memiliki imajinasi yang tinggi. Di sisi lain, anak-anak yang paham dengan pengolahan sampah ini, secara langsung ataupun tidak, dapat menyalurkan ilmunya kepada orang tua mereka. Hal ini dapat menciptakan masyarakat yang peduli terhadap sampah. Salah satu metode yang dapat ditawarkan adalah melalui program edukasi anak usia dini tentang pengolahan sampah.

\section{KEGIATAN PENGABDIA MASYARAKAT}

Program yang dilakukan diantaranya mengadakan sosialisasi dan praktek langsung pemilahan sampah dalam keseharian serta kompetisi pemanfaatan sampah menjadi barang berguna pakai. Kegiatan ini diharapkan dapat berkontribusi pada pengurangan sampah tidak yang tidak membusuk dan memberikan pengetahuan dalam penanganan sampah sejak dini sehingga terwujud generasi yang peduli terhadap sampah. Melalui kegiatan diharapkan pemahaman siswa sekolah dasar meningkat dan adanya kemandirian untuk melakukan daur ulang sampah.

\section{METODE PELAKSANAAN}

Kegiatan dilakukan di SDN 03 Cempaka Putih Ciputat Timur, Tangerang Selatan pada bulan Maret 2017. Kegiatan yang dilakukan yaitu sosialisasi, lomba daur ulang, dan monitoring. Sosialisasi dilakukan dengan presentasi dan permainan interaktif untuk siswa kelas 4 dan 5 . Materi presentasi adalah mengenai cara pemilahan sampah dan bahaya sampah bila tidak dikelola. Setiap kelompok siswa membawa bahan untuk lomba daur ulang. Bahan lomba didapat dari pembungkus makanan ringan. Setelah itu siswa dipersilahkan berkreasi untuk mendaur ulang sampah yang dibawa menjadi barang yang dapat digunakan. Hasil kreasi dari tiap kelompok kemudian dipresentasikan oleh perwakilan kelompok. Tahapan monitoring dilakukan dengan wawancara dan pengamatan langsung di sekolah.

\section{HASIL KEGIATAN}

\section{Sosialisasi}

Sosialisasi dilakukan bertujuan agar siswa memahami materi yang akan disampaikan sehingga target kegiatan dapat tercapai. Siswa merespon dengan senang hati dan antusias dalam menjawab beberapa pertanyaan sederhana yang diberikan oleh tim. Berdasarkan hasil tanya jawab awal tersebut maka tim menyusun permainan yang akan dilaksanakan pada acara pelatihan.

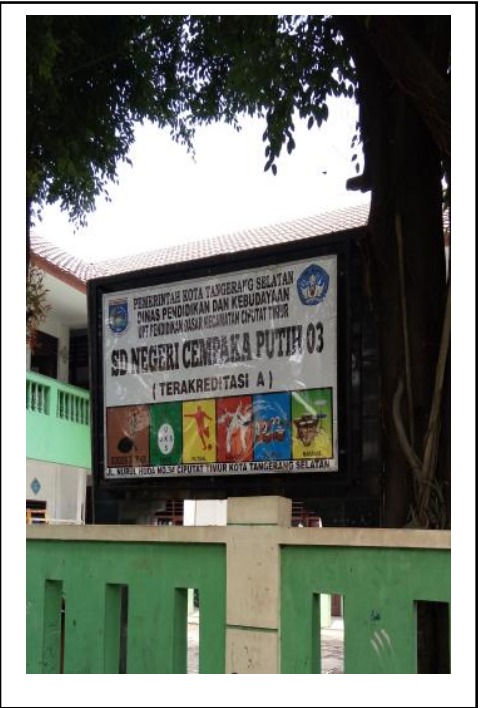

Gambar 1. Lokasi abdimas SDN Cempaka Putih 03 Jl. Nurul Huda, Ciputat Timur

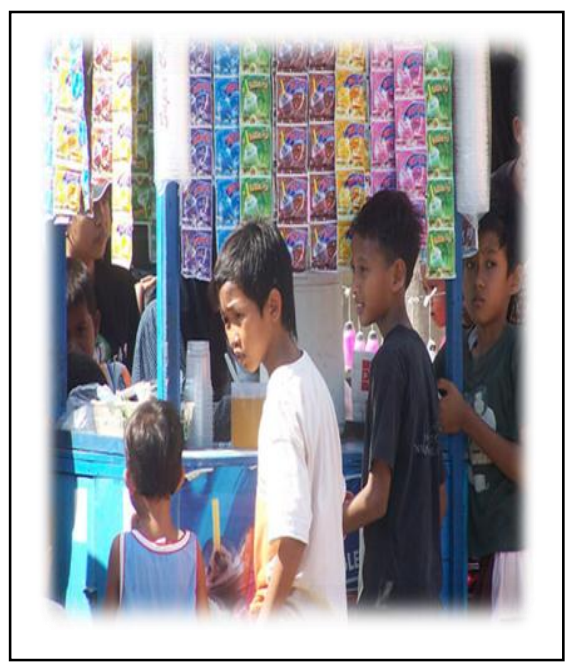

Gambar 2. Pembungkus jajanan di sekitar sekolah yang dapat digunakan untuk kegiatan oleh siswa 


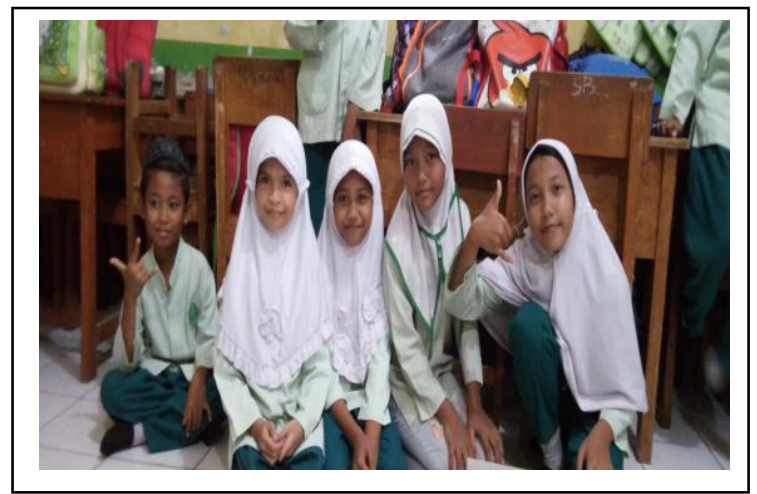

Gambar 3. Siswa kelas 4 yang mengikuti kegiatan

\section{Lomba Daur Ulang}

Lomba daur ulang diikuti oleh siswa kelas 4 dan 5 yang masing-masing terdiri atas 5 kelompok, sehingga total ada 10 kelompok. Barang yang dibuat diharapkan memiliki kegunaan pemakaian. Barang yang berhasil dibuat oleh para siswa antara lain tempat tisu, wadah bunga, kotak sampah, mainan mobil, mainan kapal, tas sekolah, dan buku catatan. Berikut merupakan contoh kegiatan tersebut.

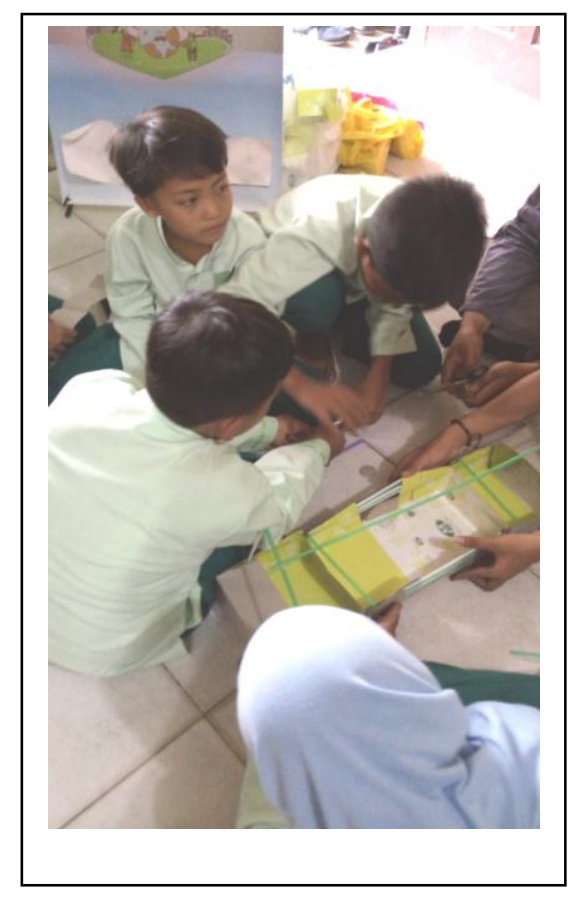

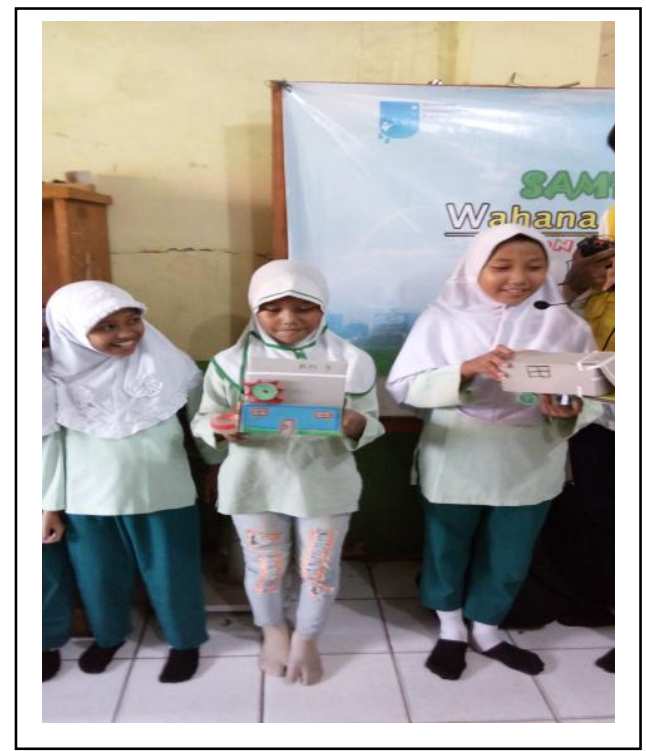

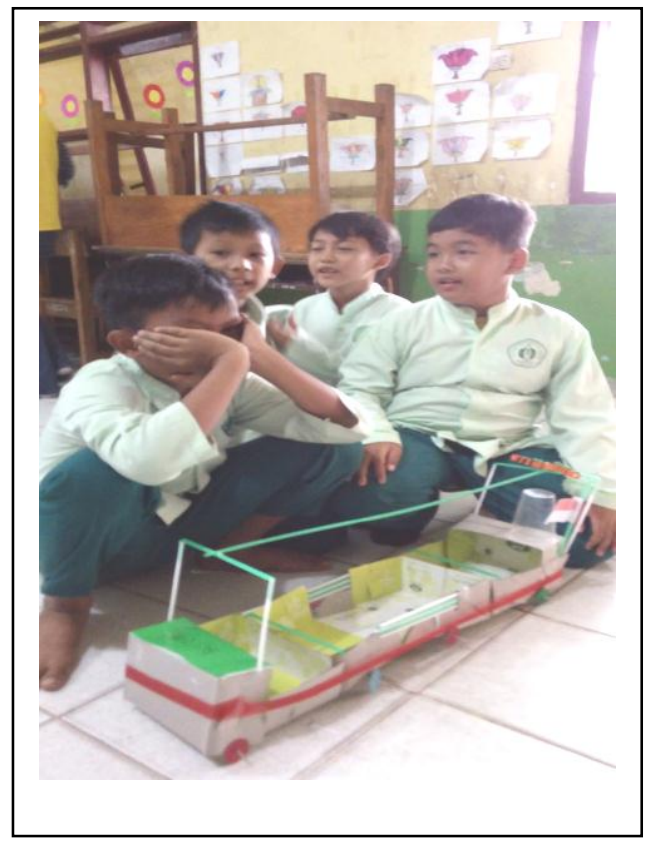

Gambar 4. Beberapa benda hasil kreativitas siswa pada kegiatan lomba daur ulang yang diikuti oleh siswa kelas 4 dan 5. (a) Mobil-mobilan, (b) Tas, (c) Kapal-kapalan.

\section{Monitoring dan Evaluasi}

Kegiatan monitoring dilakukan dengan mengunjungi kembali sekolah dan melakukan pengamatan terhadap perilaku siswa dalam memanfaatkan sampah. Perilaku yang diamati yaitu keinginan dan kemampuan siswa untuk memanfaatkan bungkus plastik bekas pembungkus makanan ringan. Dari 2 kelas yang diamati hampir seluruh siswa sudah tidak membuang bekas pembungkus tersebut namun 
mengubahnya menjadi berbagai wadah yang punya nilai manfaat. Wadah daur ulang tersebut antara lain tempat tissu, uang logam, sisa rautan pensil, dan kapur tulis. Beberapa siswa membuatnya ada yang berkelompok. Kegiatan monitoring didampingi oleh guru kelas.

\section{KESIMPULAN DAN SARAN}

Kegiatan sosialisasi dan pelatihan daur ulang sampah kepada siswa Sekolah Dsar telah berhasil dipahami dan dipraktekkan dalam keseharian siswa. Berdasarkan pantauan selama kegiatan berlangsung maka perlu dilakukan monitoring yang kontinyu sehingga dapat menjadi kebiasaan bagi siswa di masa yang akan datang.

\section{DAFTAR PUSTAKA}

[1] World Waste Facts. 2016. The World Counts. http://www.theworldcounts.com /counters/shocking_environmental_facts _and_statistics/world_waste_facts. (Diak ses pada 7 Oktober 2016).
[2] Ashari, M. 2015. Anggaran Terbatas, Pengelolaan Sampah Plastik Tidak Maksimal. $\quad$ http://www.pikiranrakyat.com/jawabarat/2015/12/14/353654/anggaranterbatas-pengelolaan-sampah-tidakmaksimal.(Diakses pada 7 Oktober 2016)

[3] Suriyani, D.L. 2016. Melihat Sampah yang Artistik dan Trendi di TrashStock. http://www.mongabay.co.id/tag/daurulang-sampah/. (Diakses pada 7 Oktober 2016)

[4] Miller Jr, G.T., 1997. Environment Science. Sixth Edition. United States of America: Wadsworth Publishing Company. Hal:335-346.

[5] Suryati,T. 2009. Bijak \& Cerdas Mengolah Sampah, Membuat Kompos Dari sampah Rumah Tangga. Jakarta: Agro Media Pustaka.

[6] Basriyanta. 2007. Memanen Sampah. Yogyakarta: Kanisius. Hal:18-19.

[7] Zulkifli, A. 2014. Dasar-Dasar Ilmu Lingkungan. Jakarta: Salemba Teknika.

[8] Warsidi, E. 2009. Mengolah Sampah Menjadi Kompos. Bekasi: Mitra Utama. 